\title{
PERAN PENDIDIKAN VOKASI DALAM PEMBANGUNAN EKONOMI
}

\author{
Slamet PH.
}

FT Universitas Negeri Yogyakarta (e-mail: slametph@yahoo.com; HP. 0811181320)

\begin{abstract}
The Contribution of Vocational Education to Economic Development. One of the challenges lying ahead is how to improve the contribution of vocational education to economic development. Several studies confirm that such contribution is very significant. In the current practices of vocational education, however, there is still a mismatch among quantitative, qualitative, location, and time requirements that stem from the world of work. The world of work requires that vocational education produce graduates that are in line with those four requirements. Efforts to maximize the contribution of vocational education to economic development can be undertaken by offering vocational education based on Indonesian characteristics, strengthening link and match with the world of work, integrating soft skills into learning, and implementing entrepreneurship education (small scale enterprise education).
\end{abstract}

Keywords : vocational education, economic development, link and match, soft skills, and entrepreneurship

\section{PENDAHULUAN}

Pendidikan, termasuk pendidikan vokasi, memiliki peran penting dalam pengembangan manusia seutuhnya dan pembangunan masyarakat Indonesia seluruhnya. Pengembangan manusia harus dilakukan secara utuh, yang mencakup pengembangan daya pikir, daya qolbu, daya fisik, dan penguasaan ilmu pengetahuan, teknologi, seni serta olah raga. Selain itu, pengembangan manusia juga diharapkan menghasilkan manusia yang mampu dan sanggup berperan aktif dalam membangun masyarakat Indonesia seluruhnya. Sukses tidaknya peran pendidikan vokasi dapat diukur dari keseimbangan dua tujuan tersebut, yaitu pengembangan manusia seutuhnya dan pembangunan masyarakat Indonesia seluruhnya.
Lebih rinci, tujuan pendidikan vokasi mencakup empat dimensi utama, yaitu:(1)mengembangkan kualitas dasar manusia yang meliputi kualitas daya pikir, daya qolbu, daya fisik; (2) mengembangkan kualitas instrumental/kualitas fungsional, yaitu penguasaan ilmu pengetahuan, teknologi, seni, dan olah raga; (3) memperkuatjatidirisebagaibangsa Indonesia; dan (4) menjaga kelangsungan hidup dan perkembangan dunia (Slamet PH, 2009). Berikut diuraikan seperlunya dari masing-masing dimensi tujuan pedidikan vokasi tersebut.

Pertama, mengembangkan kualitas dasar peserta didik yang meliputi kualitas daya pikir, daya qolbu, dan daya fisik dapat dirincikan sebagai berikut. Pengembangan kualitas daya pikir meliputi antara lain, cara berfikir analitis, 
deduktif, induktif, ilmiah, kritis, kreatif, nalar, lateral, dan berfikir sistem. Pengembangan daya qolbu meliputi, antara lain iman dan takwa terhadap Tuhan Yang Maha Esa, rasa kasih sayang, kesopansantunan, integritas, kejujuran dan kebersihan, respek terhadap orang lain, beradap, bermartabat, bertanggung jawab, toleransi terhadap perbedaan, kedisiplinan, kerajinan, beretika, beresteti$\mathrm{ka}$, dan masih banyak dimensi-dimensi qolbu yang lain. Pengembangan daya fisik meliputi kesehatan, ketahanan, kestaminaan, dan bahkan keterampilan.

Kedua, mengembangkan kualitas instrumental/fungsional/penguasaan ilmu pengetahuan dan teknologi, seni serta olahraga yang meliputi, antara lain: penguasaan mono-disiplin, multi-disiplin, antar-disiplin, lintas-disiplin, baik disiplin ilmu lunak (sosiologi, sejarah, ekonomi, politik, budaya, dan sebagainya) maupun disiplin ilmu keras (matematika, fisika, kimia, biologi dan astronomi) beserta terapannya, yaitu teknologi konstruksi, manufaktur, transportasi, telekomunikasi, teknologi bio, teknologi energi, dan teknologi bahan). Penguasaan seni meliputi seni tari, seni musik, seni suara, seni kriya, seni rupa beserta kombinasinya.

Ketiga, memperkuat jati diri (karakter) sebagaibangsa Indonesia yang mencintai tanah air melalui 4 pilar kehidupan bangsa Indonesia, yaitu Pancasila, UUD 1945, NKRI, dan Bhineka Tunggal Ika, tetap setia dan menjaga keutuhan NKRI. Setia terhadap NKRI diindikatorkan seperti (1) memahami, menyadari, menjadikan hati nurani, mewajibkan hati nurani, mencintai dan bertindak nyata dalam menjaga dan mempertahan- kan keutuhan NKRI; (2) mampu menangkal manakala terjadi benturan antarnilai akibat globalisasi yang melanda dan merongrong keutuhan NKRI; dan (3) melestarikan nilai-nilai luhur bangsa Indonesia dan sekaligus terbuka terhadap gesekan-gesekan dengan kemajuan negara-negara lain.

Keempat, menjaga kelangsungan hidup dan perkembangan dunia yang diuraikan sebagai: (1) menjaga kelangsungan hidup dan perkembangan dunia melalui wadah-wadah kolektif yang telah ada (Perserikatan Bangsa-Bangsa dan cabang-cabangnya); (2) menjaga pembangunan dunia yang berkelanjutan dari perspektiflingkungan, ekonomi, dan sosio-kultural; dan (3) secara reaktif, aktif, dan proaktif menjaga kelangsungan hidup dan perkembangan dunia, baik dari perspektif ekonomi, politik, lingkungan hidup, maupun sosio-kultural.

Untukmencapai tujuan tersebut, perlu dilakukan upaya-upaya secara sistem (utuh dan benar). Namun, fokus perhatian tulisan ini dibatasi hanya untuk menjawab dua pertanyaan. Pertama, "Ilmu-ilmu apa sajakah yang seharusnya diajarkan kepada peserta didik pendidikan vokasi Indonesia agar kelakmenjadi manusia seutuhnya dan berkontribusibesar terhadap pembangunan bangsa Indonesia?"Jawabnya jelas, yaitu "Semestinya ilmu-ilmu yang diajarkan kepada peserta didik pendidikan vokasi di Indonesia adalah ilmu-ilmu yang mampu memfasilitasi pengembangan peserta didik dan yang sesuai dengan karakteristik Indonesia, yaitu Pancasila, UUD 45, NKRI, Bhineka Tunggal Ika, dan tanah air yang penuh dengan kekayaan sumberdaya alam, tanahnya 
subur, dan lautnya yang kaya ikan". Kedua, "Bagaimanakah caranya mengelola pendidikan vokasi dalam konteks otonomi daerah seperti sekarang ini agar perannya bisa optimal?" Pendidikan vokasi harus mulai mencurahkan perhatiannya terhadap kebutuhan/kearifan lokal (daerah) seraya tetap memenuhi kebutuhan nasional dan tuntutan internasional. Selain itu, prinsip-prinsip tata kelola yang baik diterapkan, yaitu demokrasi, partisipasi, transparansi, akuntabilitas, dan sebagainya untuk tidak disebut semuanya.

Mengingat pendidikan vokasi lebih dekat keselarasannya dengan perekonomian dan khususnya dengan ketenagakerjaan, sisa tulisan ini difokuskan pada pembahasan keselarasan antara pendidikan vokasi sebagai pemasok tenaga kerja dan dunia kerja sebagai pengguna lulusan pendidikan vokasi, dengan tetap menjaga keseimbangan antara pengembangan peserta didik seutuhnya dan pembangunan ekonomi masyarakat Indonesia seluruhnya. Untukitu, berturut-turut akan dipaparkan: (1) kajian peran pendidikan dalam pembangunan ekonomi; (2) kondisi penyediaan tenaga kerja; (3) permintaan tenaga kerja; dan (4) memaksimalkan peran pendidikan vokasi dalam pembangunan ekonomi, dan kemudian diakhiri dengan penutup.

\section{KAJIAN PERAN PENDIDIKAN DA- LAM PEMBANGUNAN EKONOMI}

Kajian teori dan hasil-hasil penelitian tentang peran pendidikan dalam pembangunan ekonomi telah banyak dilakukan sejak tahun 1960-an yang intinya bahwa investasi di bidang pen- didikan berkontribusi lebih besar dalam pembangunan ekonomi dibanding dengan investasi di bidang-bidang lainnya (Becker 1964; Psacharopoulous, 1987, 1994, 1997). Klaim seperti ini memang mudah dilihat buktinya. Negara-negara dengan sumberdaya alam terbatas, tetapi dengan sumberdaya manusia yang bermutu tinggi, ekonomi mereka juga maju dengan pesat, misalnya Jepang, Korea Selatan, Hongkong, Singapore, dan Cina.

Hasil-hasil penelitian selama ini juga mengukuhkan hal tersebut. Misalnya, Boediono dan McMahon (2001) menyimpulkan bahwa investasi di bidang pendidikan berkontribusi besar dalam pembangunan ekonomi di Indonesia. Direktorat Pembinaan Sekolah Menengah Kejuruan (2008)melakukan penelitian yang kesimpulannya menyatakan "terdapat hubungan positif antara rasio siswa sekolah menengah kejuruan (SMK) dan produkdomestik regional bruto (PDRB). Apabila Propinsi memiliki rasio siswa SMK rendah, cenderung memiliki nilai PDRB yang rendah. Demikian sebaliknya. Selain itu, hasil penelitiannya juga menemukan bahwa "terdapat hubungan yang positif antara rasio siswa SMK dan laju pertumbuhan ekonomi. Apabila propinsi memiliki rasio siswa SMK rendah, cenderung memiliki laju pertumbuhan ekonomi rendah". Temuan ini sesuai dengan kajian yang dilakukan oleh ADB (2008), demikian pula sebaliknya, bahwa:

"All countries invest in technical and vocational education and training (TVET) - in fact, correlations indicate that the higher the level of country income, generally the higher 
the proportion of students enrolled in TVET institutions (ADB, 2008)".

\section{PENYEDIAAN TENAGA KERJA DAN PENGANGGURAN}

Penyediaan tenaga kerja di Indonesia dilakukan melalui jalur-jalur pendidikan, pelatihan, dan pengembangan di tempatkerja.Jalur pendidikan ditempuh melalui pendidikan formal (SD, SMP, SMA, SMK, PT), nonformal dan informal (pendidikan anak usia dini, penitipan anak, kelompok bermain, taman kanak-kanak, pendidikan masyarakat). Jalur pelatihan ditempuh melalui balai latihan kerja, kursus-kursus keterampilan kejuruan, pelatihan oleh lembaga-lembaga pelatihan selain kedua tersebut). Jalur pengembangan di tempat kerja di- tempuh melalui pemagangan/pelatihan di tempat kerja.

Meskipun tidak tersedia data yang lengkap, penyediaan tenaga kerja di Indonesia cenderung monoton dan terkanalisasi pada bidang-bidang tertentu. Kelompok-kelompok bidang studi yang dikembangkan di pendidikan vokasi ya itu-itu saja, padahal tuntutan di dunia kerja sudah sangat bervariatif. Akibatnya, terjadi over-supply pada bidangbidang pekerjaan tertentu dan undersupply pada bidang-bidang pekerjaan tertentu lainnya. Data pengangguran pada Tabel 1 dan Tabel 2 berikut menunjukkan bukti over-supply tenaga kerja pada bidang-bidang pekerjaan tertentu menurut tingkat pendidikan.

Tabel 1: Tingkat Pengangguran Berdasarkan Tingkat Pendidikan

\begin{tabular}{llccc}
\hline $\begin{array}{l}\text { No } \\
\text { yang Ditamatkan }\end{array}$ & Bekerja & $\begin{array}{c}\text { Pengangguran } \\
\text { Terbuka }\end{array}$ & $\begin{array}{c}\text { \% Pengangguran } \\
\text { Terbuka }\end{array}$ & $\begin{array}{c}\text { Mengurus } \\
\text { Rumah } \\
\text { Tangga }\end{array}$ \\
\hline 1. SD ke bawah & 55.311 .859 & 2.128 .695 & $3,85 \%$ & 18.687 .802 \\
2. SLTP & 20.300 .118 & 1.657 .452 & $7,55 \%$ & 6.495 .307 \\
3. SMA & 15.625 .389 & 2.111 .256 & $11,90 \%$ & 4.248 .495 \\
4. SMK & 8.343 .840 & 1.336 .881 & $13,81 \%$ & 2.011 .819 \\
5. Diploma/Akademi & 2.887 .103 & 538.186 & $15,71 \%$ & 480.625 \\
6. Universitas & 4.937 .263 & 820.020 & $14,24 \%$ & 495.747 \\
& 107.405 .572 & 8.592 .490 & $7,41 \%$ & 32.419 .795
\end{tabular}

Sumber: Kementerian Tenaga Kerja dan Transmigrasi, 2010 
Tabel 2: Tingkat Pengangguran Berdasarkan Bidang Studi

\begin{tabular}{rlc}
\hline No & \multicolumn{1}{c}{ Bidang Studi } & Tingkat Pengangguran \\
\hline 1. & Agama dan Ilmu Kehutanan & $14 \%$ \\
2. Administrasi/Manajemen Bisnis & $15 \%$ \\
3. Administrasi/Manajemen Keuangan & $16 \%$ \\
4. Administrasi Pemerintahan & $12 \%$ \\
5. Administrasi/Manajemen Perkantoran & $12 \%$ \\
6. Arsitektur dan Perencanaan Kota & $13 \%$ \\
7. & Bahasa dan Sastra & $13 \%$ \\
8. & Ekonomi & $15 \%$ \\
9. Hukum dan Kehakiman & $11 \%$ \\
10. Humanisme/Humaniora & $18 \%$ \\
11. Ilmu Pengetahuan Alam (IPA) & $7 \%$ \\
12. Ilmu Sosial dan Politik (IPS) & $21 \%$ \\
13. Kedokteran dan Kesehatan & $18 \%$ \\
14. Kehutanan & $11 \%$ \\
15. Kesenian dan Seni Rupa & $13 \%$ \\
16. Komunikasi Massa dan Dokumentasi & $21 \%$ \\
17. Matematika dan Ilmu Komputer & $17 \%$ \\
18. Peyanan Jasa & $16 \%$ \\
19. Perikanan & $20 \%$ \\
20. Pertanian & $10 \%$ \\
21. Pertukangan, Kerajinan dan Industri & $6 \%$ \\
22. Peternakan & $26 \%$ \\
23. Psikologi & $17 \%$ \\
24. Teknik /Teknologi & $14 \%$ \\
25. Transportasi dan Komunikasi & $12 \%$ \\
26. Kependidikan dan Keguruan & $14 \%$ \\
27. Lainnya & $15 \%$ \\
\hline
\end{tabular}

Sumber: Kementerian Tenaga Kerja dan Transmigrasi, 2010

Tingkat pengangguran sebagaimana disajikan pada Tabel 1 dan Tabel 2 di atas disebabkan oleh banyak faktor, misalnya: pertumbuhan ekonomi yang rendah, jenis investasi yang padat modal, kebijakan fiskal (jenis belanja dan besar kecilnya pajak), mutu/kualitas pencari kerja rendah, informasi pasar kerja yang kurang akurat atau bahkan belum ada, kebijakan moneter, lemahnya jiwa kewirausahaan para pencari kerja, dan kultur lulusan yang selalu ingin menjadi pekerja dan bukannya ingin menjadi orang yang mempekerjakan pekerja alias wirausahawan.

\section{PERMINTAAN TENAGA KERJA}

Permintaan tenaga kerja berasal dari dunia kerja yang dimensi-dimensinya dapat diukur dari kuantitas, kualitas, lokasi, dan waktu. Kuantitas menyangkut jumlah tenaga kerja yang dibutuh- 
kan, kualitas menyangkut kualifikasi dan kompetensi yang dibutuhkan oleh dunia kerja, lokasi merujuk kepada tempat/ lokasi pekerjaan yang dibutuhkan, dan waktu merujuk kepada kapan dibutuhkan tenaga kerja. Permintaan tenaga kerja dapat dikategorikan menjadi: sektor formal dan sektor informal; publik dan private; profit dan nonprofit; dan sektor primer, sekunder, tersier, serta kuarter.

Sektor formal terdiri dari usahausaha yang secara formal memiliki ijin resmi dan mengikuti segala aturan yang berlaku untuk usaha yang bersangkutan, misalnya industri/perusahaan, bank, dan perhotelan. Sektor informal adalah jenis usaha yang umumnya tidak terikat ijin dan di Indonesia masih menyerap $65 \%$ tenaga kerja. Sektor publik pada umumnya menyangkut pelayanan pu- blik yang dilaksanakan oleh pemerintah maupun oleh masyarakat, misalnya pemerintah daerah, sekolah, perguruan tinggi, dan rumah sakit. Usaha-usaha profit, misalnya industri, bank, hotel, dan restoran. Usaha-usaha nonprofit meliputi yayasan, pendidikan, pelatihan, dan rumah sakit. Sektor primer meliputi pertanian, peternakan, perikanan, dan kehutanan. Sektor sekunder meliputi industri manufaktur, industri mobil, perusahaan sepatu, dan perusahaan televisi. Sektor tersier (jasa langsung) misalnya bank, transportasi, perhotelan, pendidikan, dan pelatihan. sektor kuarter adalah jasa yang tidak langsung, misalnya konsultan dan penasehat. Secara umum, pertumbuhan lapangan kerja untuk masing-masing sektor lamban (lihat Tabel 3 dan Tabel 4 berikut).

Tabel3:PertumbuhanEkonomi,Kesempatan Kerja, dan Elastisitas Kesempatan Kerja

\begin{tabular}{lccc}
\hline Lapangan Pekerjaan Utama & $\begin{array}{c}\text { Pertb Ek } \\
\text { 2005- 2009 }\end{array}$ & $\begin{array}{c}\text { Pertb KK } \\
\text { 2005- 2009 }\end{array}$ & $\begin{array}{c}\text { Elastisitas KK } \\
\text { 2005- 2009 }\end{array}$ \\
\hline Pertanian, & 3,84 & 0,72 & 0,19 \\
Pertambangan & 2,20 & 8,95 & 4,07 \\
Industri Pengolahan & 3,52 & 2,01 & 0,57 \\
Listrik, Gas, dan Air & 9,28 & 2,90 & 0,31 \\
Bangunan & 7,65 & 1,08 & 0,14 \\
Perdagangan Hotel & 5,34 & 3,68 & 0,69 \\
Angkutan, & 14,95 & 1,73 & 0,12 \\
Keuangan, dan Jasa Perusahaan & 7,09 & 9,23 & 1,30 \\
Jasa Kemasyarakatan & 6,39 & 6,51 & 1,02 \\
TOTAL & 5,54 & 2,42 & 0,45 \\
\hline
\end{tabular}

Sumber: Kementerian Tenaga Kerja dan Transmigrasi, 2010 
Tabel 4 : Penduduk Usia 15 Tahun ke Atas yang Bekerja menurut Lapangan Pekerjaan Utama (Jutaan)

\begin{tabular}{|c|c|c|c|c|c|c|}
\hline No & Lapangan Pekerjaan & 2005 & $\%$ & 2009 & $\%$ & $\begin{array}{c}\text { Perubahan } \\
2005-2009\end{array}$ \\
\hline 1 & Pertanian & 41.81 & 44.03 & 43.03 & 41.18 & 1.22 \\
\hline 2 & Industri & 11.65 & 12.27 & 12.62 & 12.08 & 0.97 \\
\hline 3 & Tradable $(1+2)$ & 53.46 & 56.30 & 55.65 & 53.26 & 2.19 \\
\hline 4 & Bangunan & 4.42 & 4.66 & 4.61 & 4.41 & 0.19 \\
\hline 5 & Perdagangan & 18.90 & 19.91 & 21.84 & 20.90 & 2.94 \\
\hline 6 & Transportasi & 5.55 & 5.84 & 5.95 & 5.69 & 0.4 \\
\hline 7 & Keuangan & 1.04 & 1.10 & 1.48 & 1.42 & 0.44 \\
\hline 8 & Jasa Kemasyarakatan & 10.58 & 11.14 & 13.61 & 13.03 & 3.03 \\
\hline 9 & Lainnya & 1.00 & 1.05 & 1.35 & 1.29 & 0.35 \\
\hline \multirow[t]{2}{*}{10} & Non-tradable $(4+5+6+7+8+9)$ & 41.49 & 43.70 & 48.84 & 46.74 & 7.35 \\
\hline & Total & 94.95 & 100.00 & 104.49 & 100.00 & 19.08 \\
\hline
\end{tabular}

Sumber: Kementerian Tenaga Kerja dan Transmigrasi, 2010

Memperhatikan Tabel 3 dan Tabel 4 di atas, kelihatan bahwa pertumbuhan sektor formal kecil dan lagi pula daya serap tenaga kerja sektor formal tersebut juga kurang dari sepertiga jumlah penyerapan keseluruhan tenaga kerja. Jalan keluarnya, kecuali memacu pertumbuhan ekonomi pada sektor-sektor tersebut melalui kebijakan-kebijakan fiskal dan moneter yang mampu mendorong pertumbuhan ekonomi dan penyerapan tenaga kerja lebih besar, juga perlu ditempuh melalui pengembangan kewirausahaan dengan ekonomi kreatif. Yang terakhir, ini penting karena kultur lulusan pendidikan kita cenderung ingin menjadipekerja dan kurang bahagia untuk berusaha sendiri maupun sebagai pemilik pekerjaan yang mempekerjakan orang lain. Padahal, kenyataan ekonomi kita sangatmembutuhkan generasimuda yang berjiwa kewirausahaan.

\section{MEMAKSIMALKAN PERAN PENDI- DIKAN VOKASI DALAM PEMBA- NGUNAN EKONOMI}

Agar tujuan pendidikan vokasi benar-benar mampu memaksimalkan perannya dalam pengembangan peserta didikseutuhnya dan pembangunan ekonomi, perlu ditempuh upaya-upaya sebagai berikut (selektif).

- Ilmu-ilmu yang diajarkan kepada peserta didik pendidikan vokasi semestinya ilmu-ilmu yang cocok untuk memfasilitasi pengembangan peserta didik agar menjadi manusia seutuhnya dan ilmu-ilmu yang sesuai dengan karakteristik Indonesia sebagaimana disebut sebelumnya. Keduanya sama-sama diperlukan dan jangan sampai terpeleset mengorbankan salah satu. Mengorbankan pengembangan eksistensi peserta didikberartimendehumanisasi manusia dan mengembangkan peserta didik yang tidak ada keselarannya dengan kebutuhan masyarakat, khususnya dunia kerja, akan membuat pendidikan vokasi 
terisolasi dan terlepaskan dari kaitannya dengan masyarakat, terutama dengan dunia kerja. Jika ini terjadi, maka pendidikan vokasi tidak berperan sama sekali terhadap pembangunan masyarakat.

- Memperkuat kemampuan soft skills peserta didik pendidikan vokasi melalui berbagai ragam cara. Secara matematis, soft skills = kualitas intrapersonal + keterampilan interpersonal.

Kualitas intrapersonal adalah kualitas batiniah (kualitas rohaniah) manusia yang bersumber dari dalam lubuk hati manusia yang dimensi-dimensinya meliputi antara lain kerendahan hati, harga diri, integritas, tanggung jawab, komitmen, motivasi diri, rasa keingintahuan, menyukai apa yangbelum diketahui (umumnya manusia menyukai apa yang sudah diketahui), kejujuran, kerajinan, kasih sayang (cinta sesama), disiplin diri, kontrol diri, kesadaran diri, dapat dipercaya, dan berjiwa kewirausahaan dimana yang terakhir ini umumnya bersumber dari pendidikan yang memerdekakan manusia sehingga tidak tertekan dan menjadi kreatif yang akibatnya menjadi inovatif dan mampu membentuk jiwa kewirausahaan manusia. Tentu saja masih banyak dimensi kualitas intrapersonal yang lain, tetapi terlalu banyak untuk disebut satu per satu. Keterampilan interpersonal adalah keterampilan yang berkaitan dengan hubungan antarmanusia yang dimensi-dimensinya meliputi antara lain bertanggung jawab atas semua perbuatannya, sikap hormat/respek kepada orang lain, perdamaian, kecintaan kepada sesama, komunikasi yang mengenakkan, kepemimpinan, kerjasama/kerja kelompok, kehalusan berbudi, sosiabilitas, solidaritas, toleransitenggang rasa, bijaksana, beradap, berani berbuat benar meskipun tidak populer, demokratis, sikap adil, sikap tertib, dan masih banyak dimensi-dimensi keterampilan interpersonal lainnya yang terlalu banyak untuk disebut satu per satu. Istilah soft skills sangat erat kaitannya dengan istilah-istilah lain, seperti karakter, akhlak, budi pekerti, kecerdasan emosi, nilai-nilai kehidupan (living values), moralitas, personality, dan employability skills bagi yang sudah bekerja. Sepanjang berurusan dengan hubungan antarmanusia yang dilandasi oleh humanitas, itu disebut soft skills.

- Membangun keselarasan (link E match) dengan sistem-sistem yang lain sebagaimana tertuang dalam Gambar 1, terutama keselarasan dengan sistem ekonomi umumnya atau dunia kerja khususnya. Diupayakan, pendidikan vokasi lebih mengarah kepada demand-driven dari pada supply-driven yang dilakukan melalui pembelajaran yang lebih aktual tidak sekadar tekstual, lebih lebih konkret dari pada abstrak, yang lebih merujuk ke realita dari pada artifial, lebih nyata dari pada maya, dan ini semua menuntut pendidikan vokasi secara proaktif mendekatkan diri dengan dunia kerja. 

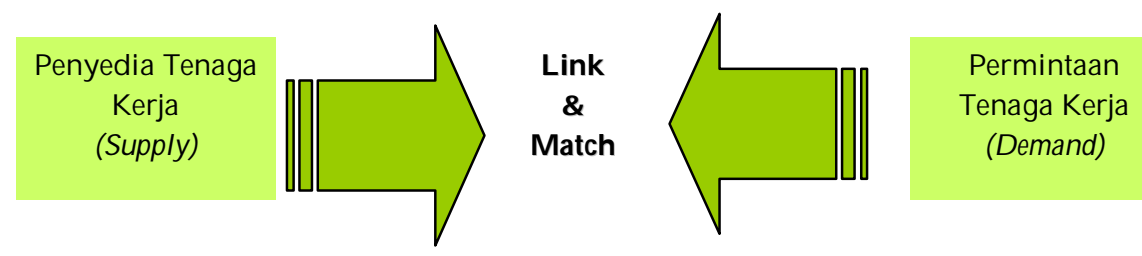

Permintaan

Tenaga Kerja

(Demand)
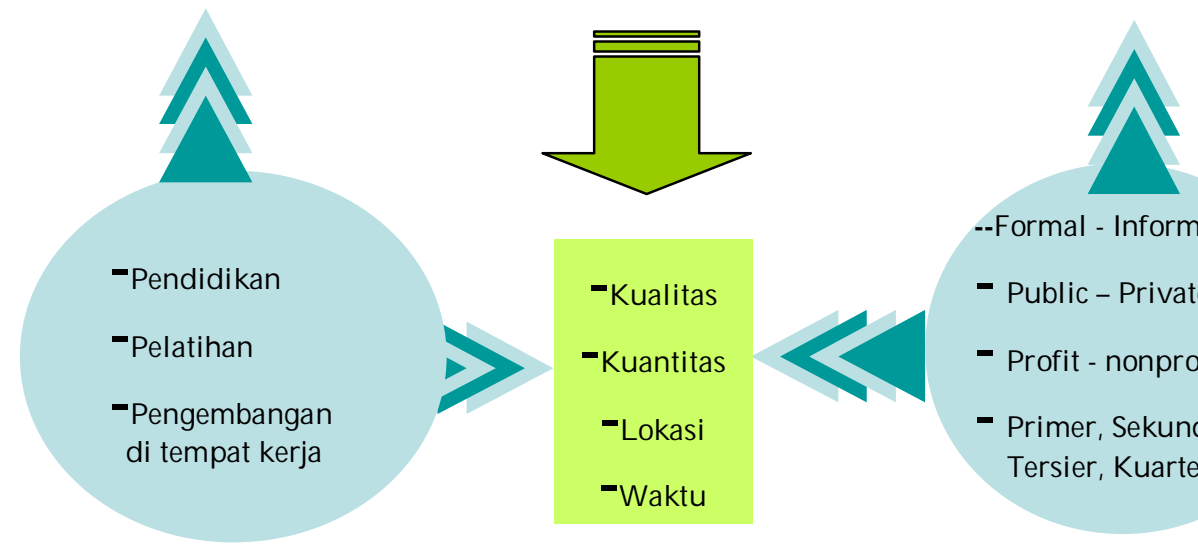

--Formal - Informal

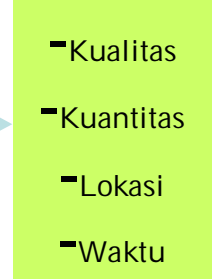

- Public - Private

- Profit - nonprofit

- Primer, Sekunder, Tersier, Kuarter

Gambar 2: Link \& Match Supply-Demand Tenaga Kerja

Kualitas Dasar Kewirausahaan

- Mengajarkan kewirausahaan kepada

- Daya Pikir peserta didik pendidikan vokasi melalui pengetahuan, penyadaran, dan praktek-praktek yang nyata/aktual tentang kewirausahaan. Peserta didik harus diajarkan tentang karakteristik kewirausahaan sukses sebagai berikut. Setidaknya, ada dua jenis karakteristik atau dimensi kewirausahaan yaitu: (1) kualitas dasar kewirausahaan, yang meliputi kualitas daya pikir, daya hati/qolbu, dan daya fisik; dan (2) kualitas instrumental kewirausahaan, yaitu penguasaan lintas disiplin ilmu. Berikut dijabarkan seperlunya tentang dua karakteristik kewirausahaan yang dimaksud (Slamet PH, 2010).

Kualitas dasar daya pikir kewirausahaan memiliki karakteristik/dimensi-dimensi sebagai berikut: berpikir kreatif; berpikir inovatif; berpikir asli/baru/ orisinil; berpikir divergen; berpikir mengembangkan; pionir berpikir; berpikir menciptakan produk dan layanan baru; memikirkan sesuatu yang belum pernah dipikirkan oleh orang lain; berpikir sebab-akibat; berpikir lateral; berpikir sistem; berpikir sebagai perubah (agen perubahan); berpikir kedepan (berpikir futuristik); berintuisi tinggi; berpikir maksimal; terampil mengambil keputusan; berpikir positif; berpikir alternatif, berpikir reflektif, dan versalitas berpikir sangat tinggi.

- Daya Qolbu/Hati 
Kualitas dasar daya hati/qolbu kewirausahaanmemilikikarakteristik/dimensi-dimensi seperti: prakarsa/misiatif tinggi; ada keberanian moral untuk mengenalkan hal-hal baru; proaktif, tidak hanya aktif apalagi hanya reaktif; berani mengambil resiko; berani berbeda; pro perubahan dan bukan pro kemapanan; kemauan, motivasi, dan spirit untuk maju sangat kuat; memiliki tanggung jawab moral yang tinggi; hubungan interpersonal bagus; berintegritas tinggi; gigih, tekun, sabar, dan pantang menyerah; bekerja keras; berkomitmen tinggi; memiliki kemampuan untuk memobilisasi orang lain; melakukan apa saja yang terbaik; melakukan perbaikan secara terus-menerus; mau memetik pelajaran dari kesalahan, dari kesuksesan, dan dari praktek-praktek yang baik; membangun teamwork yang kompak, cerdas, dinamis, harmonis, dan lincah; percaya diri; pencipta peluang; memiliki sifat daya saing tinggi, tetapi mendasarkan pada nilai solidaritas; agresif/ ofensif; sangat humanistik dan hangat pergaulan; terarah pada tujuan akhir, bukan tujuan sesaat; luwes dalam pergaulan; selalu menginginkan tantangan baru; selalu membangun keindahan cita rasa melalui seni (kriya, musik, suara, tari, lukis, dan sebagainya); bersikap mandiri akan tetapi supel; tidak suka mencari kambing hitam; selalu berusaha menciptakan dan meningkatkan nilai tambah sumberdaya; terbuka terhadap umpan balik; selalu ingin mencari perubahan yang lebih baik (meningkatkan/mengembangkan); tidak pernah merasa puas, terus-menerus melakukan inovasi dan improvisasi demi perbaikan selanjutnya; dan keinginan menciptakan sesuatuyang baru.

\section{- Daya Fisik}

Kualitas dasar daya pisik/raga kewirausahaan memiliki karakteristik/dimensi-dimensi seperti: menjaga kesehatan secata teratur; memelihara ketahan/stamina tubuh dengan baik; memiliki energi yang tinggi; dan keterampilan tubuh dimanfaatkan demi kesehatan dan kebahagiaan hidup.

\section{Kualitas Instrumental Kewirausahaan}

Jika seseorang ingin menjadi wirausahawan sukses, maka selain memiliki kualitas dasar kewirausahaan sebagaimana diuraikan sebelumnya, dia harus juga memiliki kualitas instrumental kewirausahaan yang kuat, yaitu penguasaan disiplin ilmu, baik mono disiplin ilmu, antardisiplin ilmu, maupun lintas disiplin ilmu. Kewirausahaan bukanlah sekadar mono-disiplin (ekonomi, matematika, manajemen, dan sebagainya) dan juga bukan hanya antardisiplin ilmu (manajemen perusahaan, ekonomi pertanian, psikologi industri, dan sebagainya), akan tetapi juga lintas disiplin ilmu (lingkungan hidup, kependudukan, dan sebagainya).

Seseorang yang ingin menjadi wirausahawan sukses tidak cukup hanya memiliki kualitas dasar kewirausahaan, akan tetapi yang bersangkutan harus juga memiliki kualitas instrumental kewirausahaan (penguasaan disiplin ilmu). Misalnya, jika seseorang ingin menjadi wirausahawan sebagai pengusaha, dia harus memiliki ilmu-ilmu, seperti: manajemen produksi (proses produksi, rencana produksi, riset dan pengembangan 
produksi), manajemen pemasaran (perebutan pelanggan, rencana pemasaran, riset pasar dan pemasaran), manajemen sumberdaya manusia, manajemen keuangan, manajemen peralatan dan perbekalan, prinsip-prinsip akuntansi, manajemen transaksi, dan inti manajemen.

\section{Cara Mengembangkan Kewirausahaan}

Cara-cara mengembangkan kewirausahaan dilakukan melalui pentahapan sebagai berikut. Pertama, melakukan evaluasi diri tentang tingkat/level kepemilikan kewirausahaan. Ini dapat dilakukan melalui pengisian daftar kualitas kewirausahaan atau menjawab sejumlah pertanyaan tentang kewirausahaan yang dilakukan setulus-tulusnya dan sejujur-jujurnya (lihat Instrumen Profil Diri Kualitas Dasar Kewirausahaan oleh Slamet PH). Hasil pengisian daftar jawaban tersebut berupa profil diri kewirausahaan. Kedua, berdasarkan hasil evaluasi diri (profil diri jiwa kewirausahaan), selanjutnya ditempuh melalui berbagai upaya yang disebut "belajar". Ketiga, mempelajari kewirausahaan dapat dilakukan melalui berbagai upaya, misalnya: berpikir sendiri (otak kita kaya untuk berpikir), membaca (buku, jurnal, internet/web-site), magang, kursus pendek, belajar dari wirausahawan sukses, pengamatan langsung dilapangan, dialog dengan wirausahawan sukses, mengikuti seminar, mengundang wirausahawan sukses, menyimak acara-acara kewirausahaan di televisi, atau caracara lain yang dianggap tepat bagi dirinya untuk mempelajari kewirausahaan.

Selain itu, pendidikan kewirausahaan dengan mudah dapat dintegrasikan ke dalam kurikulum. Ini tidak lantas harus disediakan pelajaran tersendiri untuk mengenalkan dan mengakrabkan pendidikan kewirausahaan kepada peserta didik. Pada dasarnya, setiap mata pelajaran dapat menjadi wahana untuk mengenalkan dan mengakrabkan pendidikan kewirausahaan. Berikut disampaikan beberapa cara pengintegrasian pendidikan kewirausahaan ke dalam kurikulum.

Pertama, pendidikan kewirausahaan diintegrasikan pada setiap mata pelajaran, topik atau sub-topik mata pelajaran yang sesuai dengan tujuan yang akan dicapai oleh pendidikan kewirausahaan. Jadi, guru/dosen harus menyeleksi dan mengorganisasikan dimensi-dimensi pendidikan kewirausahaan mana yang secara koheren dapat diintegrasikan ke dalam mata pelajaran, topik atau subtopik mata pelajaran. Misalnya, pendidikan kewirausahaan tentang kejujuran, tanggung jawab, kemandirian, dan kedisiplinan dapat diintegrasikan dalam topik atau sub-topik mata pelajaran matematika, fisika, kimia, biologi, mekanika, dan sebagainya dalam praktikum/ eksperimen yang dilakukan secara mandiri oleh peserta didik. Contoh lain,, pendidikan kewirausahaan yang meliputi sikap hormat/respek kepada orang lain, komunikasi, kepemimpinan, kerja kelompok, sosiabilitas, solidaritas, kerjasama, dan toleransi terhadap perbedaan, dapat diintegrasikan dalam mata pelajaran, topik atau sub-topik mata pelajaran yang relevan (misalnya mata pelajaran PKN, IPS, dan Bahasa Indonesia) dapat dilaksanakan dengan metode diskusi, kerja kelompok, dan curah pendapat. 
Kedua, pendidikan kewirausahaan diintegrasikan ke dalam mata pelajaran, topik, sub-topik mata pelajaran yang dilakukan melalui simulasi kewirausahaan yang dilaksanakan di sekolah. Misalnya, jika ingin mengenalkan dan mengakrabkan employability skills (etika kerja, kedisiplinan, hubungan antarmanusia, motivasi kerja, kerjasama, dan kewirausahaan) kepada peserta didik, maka simulasi beberapa mata pelajaran yang mengandung employability skills dapat dilakukan. Implikasinya, guru/dosen harus mampu melakukan seleksi dan organisasi pengalaman belajar yang secara koheren layak dan bermakna untuk disimulasikan.

Ketiga, pendidikan kewirausahaan diintegrasikan ke dalam setiap mata pelajaran, topik atau sub-topik mata pelajaran yang dirancang untuk disampaikan secara sendiri melalui kursus pendek tentang pentingnya pendidikan kewirausahaan bagi penerapan mata pelajaran tersebut dalam kehidupan (aktual, konkret, realitas, nyata). Implikasinya, guru mengidentifikasi pendidikan kewirausahaan mana yang akan disampaikan melalui kursus pendek. Kursus boleh dilaksanakan secara gabungan dengan mata pelajaran lain (lintas mata pelajaran) sekiranya kompatibel dengan pendidikan kewirausahaan yang diinginkannya.

Keempat, pendidikan kewirausahaan dapat di integrasikan ke dalam setiap mata pelajaran, topik atau sub-topik mata pelajaran yang kemudian pelaksanaannya dilakukan di tempat kerja (pengalaman kerja di dunia kerja), baik dalam bentuk magang, nyantrik, internship maupun bentuk-bentuk lain yang sesuai dengan pendidikan kewirausahaan yang diinginkan. Implikasinya, guru/donen melakukan seleksi dan organisasi topik/sub-topik mata pelajaran yang akan dilaksanakan di dunia kerja. Selanjutnya, kerjasama dengan dunia kerja harus dilakukan oleh para guru/ donen mulai dari perancangan, pelaksanaan hingga sampai evaluasinya. Ini cocok untuk sekolah menengah kejuruan, politeknik, akademi, sekolah tinggi, dan universitas.

Kelima, pendidikan kewirausahaan di integrasikan ke dalam setiap mata pelajaran, topik atau sub-topik mata pelajaran yang dilakukan melalui pemberian contoh oleh dosen/guru dalam setiap mengajar topik/sub topik tertentu sehingga dosen/guru mengajar bergerak dari serba abstrak ke konkret, dari maya ke nyata, dari artifisial ke realita, dan dari tekstual ke aktual. Di sinilah tantangan yang di hadapi oleh dosen/ guru dalam menyeleksi dan mengorganisasikan bahan ajar yang dapat di masuki pendidikan kewirausahaan.

Keenam, pendidikan kewirausahaan dapat diintegrasikan ke dalam mata pelajaran, topik, sub-topik mata pelajaran yang dilakukan melalui seleksi dan organisasi pengalaman belajar yang memerlukan kunjungan ke dunia kerja/masyarakat, mengundang narasumber dari dunia kerja/tokoh masyarakat, dan yang menggunakan jasa komputer/web-site yang secara koheren layak dan bermakna dalam pelaksanaan mata pelajaran tertentu. Penyediaan bacaan-bacaan tentang penerapan pendidikan kewirausahaan yang terkait dengan mata pelajaran - mata pelajaran tertentu yang akan diaplikasikan dalam kehidupan sehari- 
hari atau yang akan diterapkan dalam dunia kerja, baik dalam sektor publik maupun swasta.

\section{PENUTUP}

Pendidikan vokasi dapat berperan maksimal dalam pembangunan ekonomi jika keselarasannya dengan dunia kerja di sekitarnya diupayakan secara terus-menerus, baik dalam dimensi kuantitas, kualitas, lokasi, maupun waktu. Pendidikan vokasi juga akan berperan maksimal dalam pembangunan ekonomi jika mampu mengintegrasikan program-programnya dengan keberadaan regulasi, kebijakan, perencanaan, dan penganggaran pemerintah di era otonomi daerah seperti saat ini.

\section{UCAPAN TERIMA KASIH}

Penulis mengucapkan terima kasih kepada Kementerian Tenaga Kerja dan Transmigrasi atas data dan informasi tentang pengangguran.

\section{DAFTAR PUSTAKA}

Anonim. 2009. Good Practice in Technical and Vocational Education and Training. Manila, Philipina: Asian Development Bank.

2010. Penyelarasan Pendidikan, Pelatihan dengan Dunia Kerja. Jakarta:Kementerian Tenaga Kerja dan Transmigrasi.

2010. Kerangka Kerja Penyelarasan Pendidikan dengan Dunia Kerja. Jakarta: Kementerian Pendidikan Nasional.
2008. Peran SMK dalam Mendukung Pertumbuhan Ekonomi Daerah. Jakarta: Direktorat Pembinaan Sekolah Menengah Kejuruan.

Becker, G.S. 1964. Human Capital. New York, NY.: National Bureau of Economic Research.

Boediono \& McMahon. 2001.Pembangunan Pendidikan untuk Mendukung Pertumbuhan Ekonomi. Jakarta: Badan Penelitian dan Pengembangan, Departemen Pendidikan dan Kebudayaan.

Psacharopoulous, G. 1997. "Vocational Education and Training Today: Challenges and Responses". Journal of Vocational Education and Training, 49 (3), h.385-393.

Psacharopoulous, G. 1994. "Returns to Investment in Education: A Global Update". Wolrd Development, Vol. 22 (9), h.1325-1343.

Psacharopoulous, G. 1987. “To Vocationalize or Not to Vocationalize: That is the Curriculum Question". Internationale Review of Education, 33 (2), h.187-211.

Psacharopoulous, G. 1986. Education for Development: An Analysis of Investment Choices. Washington, DC.: The World Bank.

Slamet PH. 2010. "Kewirausahaan". Makalah Penataran Pengawas Sekolah. Jakarta: Kementerian Pendidikan Nasional. 
2010. Peran Pendidikan Vokasi di Era Otonomi Daerah (Orasi Ilmiah Disampaikan pada Acara Wisuda Angkatan IX Tahun 2010 STMIK Bina Patria Magelang Pada 18 Desember 2010 di Magelang).

.2010. "PersonalCharacters Required by the Workplaces". Paper Presented at the International Seminar on Vocational Education and Training. Jogjakarta: Jogyakarta State University.
.2009. "Pengintegrasian Hard Skills and Soft Skills dalam Kuri"kulum." Makalah Dipresentasikan pada Seminar Internasional dengan tema "Pengintegrasian Hard Skills dan Soft Skills". Medan: Universitas Negeri Medan. 
